\title{
LAYANAN BIMBINGAN DAN KONSELING DALAM MENGATASI SISWA UNDERACHIEVER
}

\author{
Beny Dwi Pratama ${ }^{1}$, Suharni $^{2}$ \\ ${ }^{1}$ Fakultas Keguruan dan Ilmu Pendidikan, Universitas PGRI Madiun, Madiun \\ benydwipratama@unipma.ac.id \\ ${ }^{2}$ Fakultas Keguruan dan Ilmu Pendidikan, Universitas PGRI Madiun, Madiun \\ harnibk@unipma.ac.id
}

\begin{abstract}
Abstrak
Penelitian ini dilatarbelakangi oleh banyaknya anak yang mengalami prestasi yang kurang sesuai dengan kemampuan yang mereka miliki, makna lain dalam hal ini disebut underachiever. Sehingga penelitian ini bertujuan untuk menyeimbangkan mengenai kemampuan yang mereka miliki dengan keadaan atau capaian mereka. Keberadaan anak underachiever merupakan salah satu fenomena yang sampai saat ini masih terjadi di Indonesia. Seorang anak dapat dikategorikan underachiever ketika terjadi ketidaksesuaian antara kapasitas intelektual yang mereka miliki yang ditunjukkan dengan kecerdassan atau IQ tinggi dengan prestasi akademik yang mereka raih di sekolah. Banyak hal yang bisa menyebabkan anak menjadi underachiever. Salah satu alasannya adalah metode pengajaran guru yang tidak bisa dinikmati anak-anak sebagaimana mestinya. Penyebab lainnya adalah gaya belajar siswa yang tidak bisa diakomodasi di kelas. Kondisi ini sering dikaitkan dengan underachiever berbakat. Teknik analisis data dalam penelitian ini, peneliti menggunakan analisis kualitatif deskriptif (pemaparan) dan data yang peneliti peroleh baik melalui observasi, interview, dan dokumentasi dari pihak-pihak yang mengetahui tentang data yang peneliti butuhkan. Bimbingan dan konseling untuk membantu anak memahami kondisi underachiever sendiri. Panduan dan konseling yang mendalam juga dapat membantu anak menyesuaikan diri dengan belajar di kelas. Keterlibatan orang tua dalam perawatan anak dengan masalah dapat berdampak positif underachiever pada perkembangan anak.

Kata Kunci: Underachiever, Layanan Bimbingan dan Konseling
\end{abstract}

\begin{abstract}
This research is motivated by the number of children who experience the lesson of achievement in this case called underachiever. So this study aims to balance the abilities they have with their circumstances or achievements. The existence of children underachiever is one of the phenomenon that until now still occur in Indonesia. A child can be categorized as an underachiever when a discrepancy between their intellectual capacities is demonstrated by high intelligence or IQ with their academic achievement at school. Many things can cause a child to become an underachiever. One reason is the teacher teaching method that children can not enjoy properly. Another cause is the learning style of students who can not be accommodated in the classroom. This condition is often associated with a talented underachiever. Data analysis techniques in this study, the researchers used qualitative analysis descriptive (exposure) and data that the researchers obtained through observation, interviews, and documentation of the parties who know about the data that the reporters need. Guidance and counseling to help children understand underachiever conditions themselves. In-depth guidance and counseling can also help children adjust to learning in the classroom. Parental involvement in child care can be positively impact underachiever on child development.
\end{abstract}

Keywords: Underachiever, Guidance and Counseling Services 


\section{PENDAHULUAN}

Pemerintah

menyadari

pentingnya pendidikan yang bermutu

bagi bangsa Indonesia. Hal ini sesuai

dengan amanat UUD Negara Republik Indonesia Tahun 1945 pasal 31 ayat (1) dan ayat (3). Dalam proses belajar mengajar tidak menutup kemungkinana akan ditemui permasalahan, diantara permasalahan-permasalahan yang ada salah satunya terdapat massalah prestasi belajar tetapi tingkat kecerdasan yang tinggi yang sering dialami peserta didik di sekolah.

Beberapa guru dihadapkan pada karakteristik siswa yang beraneka ragam. Ada siswa yang dapat menempuh kegiatan belajar secara lancar dan berhasil tanpa mengalami hambatan, namun disisi lain tidak sedikit siswa yang justru mengalami berbagai kendala. Prestasi belajar rendah ditunjukan oleh adanya hambatan tertentu untuk mencapai hasil belajar, dapat bersifat psikologis, sosial, maupun fisiologis.

Masalah belajar diatas merupakan masalah penting yang perlu mendapat perhatian yang serius dikalangan para pendidik. Dikatakan demikinan, karena belajar rendah dengan kecerdasan tinggi yang dialami oleh peserta didik di sekolah akan membawah dampak negatif baik terhadap diri siswa tersebut maupun terhadap lingkungannnya. Salah satunya jenis masalah belajar yang sering dialami oleh siswa adalah underachiever atau keadaan dimana prestasi yang diperoleh siswa tersebut dibawah tingkat kecerdasan atau IQ yang dimilikinya.

Dilihat dari segi nilai prestasinya tinggi tetapi ia merupakan siswa yang terisolassi didalam kelasnya. Begitu juga sebaliknya siswa diliahat dari segi nilai prestasinya rendah tetapi dari segi IQ ia tergolong tinggi., hal-hal seperti inilah yang membutuhkan pemahaman yang lebih mendalam tentang jenis dan penyebab serta hambatan belajar siswa. Menurut Munandar (2002: 23), underachiever atau prestasi dibawah kemampuan adalah jika ada ketidaksesuaian antara prestasi sekolah anak dan indeks kemampuannya sebagai nyata dari tes intelegensi, prestasi atau kreativitas, atau dari data observasi, dimana tingkat prestasi sekolah nyata lebih rendah daripada tingkat kemampuan anak.

Dari pemaparan diatas disimpulkan bahwa underachiever menjadi salah satu masalah dalam dunia pendidikan untuk diatasi. Sedangkan dalam mengatasinya membutuhkan peran dari semua pihak, khususnya dalam hal ini adalah guru bimbingan dan konseling. Konselor atau guru bimbingan dan konseling perlu untuk mengidentifikasi kebutuhan anak berbakat., terutama anak yang terindifikasi underachiever. Sebab, ada beberapa faktor yang perlu diperhatikan yang dapat menjadi 
penyebabanak menjadi

underachiever.

Istilah underachiever mengacu pada siswa yang memiliki taraf intelegensi yang tinggi akan tetapi prestasi belajarnya rendah (di bawah rata-rata). Secara potensial mereka yang intelegensinya tinggi memiliki prestasi belajar yang tinggi pula. Prayitno dan Amti (2009: 99) mengungkapkan bahwa underachiever identik dengan keterlambatan ademik yang berarti bahwa keadaan siswa yang diperkirakan memiliki intelegensi yang cukup tinggi, tetapi tidak dapat memenfaatkannya secara optimal.

Layanan Bimbingan Konseling bertujuan mengembangkan seluruh potensi peserta didik secara optimal, mencegah timbulnya masalah, dan berusaha membantu memecahkan masalah peserta didik. Pelayanan bimbingan dan konseling didasarkan pada kebutuhan dan masalah peserta didik, pengalaman nyata, dan bersifat pengembangan diri yang komprehensif. Layanan bimbingan dan konseling dapat memberi kontribusi terhadap penangan masalah belajar yang sering dialami oleh siswa, khususnya keadaan dimana prestasi yang diperoleh siswa tersebut dibawah tingkat kecerdasan atau IQ yang dimilikinya yang biasanya disebut underachiever.

Underachiever adalah suatu kondisi dimana seorang anak menunjukkan prestasi yang berada di bawah kemampuan anak sesungguhnya. Hal ini biasanya terjadi pada anak-anak yang memiliki tingkat intelegensi yang tinggi namun prestasinya di sekolah berada di bawah performance anak tersebut. Pada banyak kasus anak disleksia di sekolah menunjukkan prestasi belajar yang buruk, padahal dari segi tingkat kemampuan intelegensi, mereka berada di angka rata-rata dan bahkan banyak yang di atas rata-rata. Pada anak gifted, kejadian anak mengalami underachiever adalah bisanya diakibatkan karena tingkat intelegensi mereka yang sangat tinggi, akhirnya minat mereka jadi lebih terbatas, sehingga seringkali muncul perilaku mengabaikan materi-materi yang tidak diminati, yang kemudian berdampak pada hasil tidak bagus pada materi yang tidak diminati. Hal ini terjadi bukan karena tidak mampu, melainkan karena tidak menyukai dan pada akhirnya malas untuk mempelajarinya.

Menurut Davis dan Rimm (dalam Munandar, 2004: 23) dijelaskan bahwa yang dimaksud underachiever atau berprestasi di bawah kemampuan adalah 'jika ada ketidaksesuaian antara prestasi sekolah dan indeks kemampuannya sebagaimana nyata dari tes intelegensi, prestasi atau kreativitas, atau dari data observasi, di mana prestasi sekolah nyata lebih rendah daripada tingkat kemampuan'. Selain 
itu Semiawan (dalam rahmawati, 2013: 5) menyebutkan "underachiever adalah kinerja yang secara signifikan berada di bawah potensinya".

Makmun (dalam rahmawati, 2013: 6) juga mengungkapkan bahwa yang dimaksud "underachiever adalah mereka yang prestasinya ternyata lebih rendah dari apa yang diperkirakan berdasar hasil tes kemampuan belajarnya". Underachiever banyak dialami oleh siswa di sekolah mereka menentukan prestasi yang tidak sesuai dengan IQ yang dimilikinya. Menurut Clark (dalam Rahmawati, 2015: 6) ada beberapa karakeristik yang ditunjukan siswa underachiever, yaitu sebagai berikut: 1) Menunjukan prestasi yang berlawanan dengan harapan atau potensi yangdimilikinya. 2) Merasa tidak senang dengan sekolah atau gurunya dan cenderung bergabung dengan teman yang juga memiliki sikap negatif terhadap sekolah. 3) Kurang termotivasi untuk belajar, tidak mengerjakan tugas, sering mengantuk ketika belajar dan tidak tuntas dalam mengerjakan tugas. 4) Kurang mampu melakukan penyesuaian intelektual. 5) Merasa kurang bersemangat, kurang tegas dan sering ribut di kelas. 6) Memiliki disiplin yang rendah, sering telat sekolah, enggan mengerjakan tugas, sering ribut, dan mudah terpengaruh. 7) Tidak memiliki hobi atau minat terhadap kegiatan untuk mengisi waktu luang. 8) Takut ujian dan berprestasi rendah.

Anak tidak dilahirkan sebagai underachiever. Berprestasi dibawah taraf kemampuan adalah perilaku yang dipelajari, oleh karena itu dapat juga dihindari. Menurut Gustian (dalam Tita, 2015: 34 ) menjelaskan faktor-faktor underachiever antara lain adalah sebagai berikut:

a. Lingkungan sekolah sebagai penyebab underachiever

Sekolah merupakan faktor yang sangat berperan dalam menyebabkan terjadinya underachiever pada anak. Cara pengajaran, materi-materi yang diberikan, dan ukuran-ukuran keberhasilan dan kemampuan guru dapat menjadi penyebab anak mengalami underachiever.

b. Faktor guru

Guru juga memegang peranan penting dalam prestasi sekolah anak karena gurulah yang mentransfer pengetahuan kepada anak. Bagaimana guru dalam memperlakukan anak didiknya akan mempengaruhi prestasi yang akan dicapai anak. Harapan (expectancy) guru terhadap kemampuan anak sangat berpengaruh pada penilaian anak mengenai kemampuan dirinya. 
c. Keluarga dan lingkungan rumah

Selain sekolah, lingkungan rumah juga dapat menyebabkan anak menjadi underachiever. Bagaimana orang-orang terdekat memperlakukan anak akan mempengaruhi pencapaian anak dalam berprestasi.

Bimbingan dan konseling sekolah merupakan salah satu layanan interpersonal, memiliki posisi strategis untuk membantu siswa dalam mengatasi masalah yang dihadapi. Bimbingan dan konseling juga berperan memfasilitasi perkembangan potensi yang dimiliki siswa. Tujuan pelayanan bimbingan dan konseling di sekolah agar konseli dapat:

$\begin{array}{lrr}\text { 1. Merencanakan } & \text { kegiatan } \\ \text { penyelesaian } & \text { studi, } \\ \text { perkembangan } & \text { karir } & \text { serta } \\ \text { kehidupannya di masa } & \text { yang } \\ \text { akan datang. } & & \end{array}$

2. Mengembangkan seluruh potensi dan kekuatan yang dimiliki seoptimal mungkin.

3. Menyesuaikan diri dengan lingkungan pendidikan, lingkungan masyarakat serta lingkungan kerjanya.

4. Mengatasi hambatan dan kesulitan yang dihadapi dalam studi, penyesuaian dengan lingkungan pendidikan, masyarakat, maupun lingkungan kerja (Depdiknas, 2007).
Pelayanan bimbingan dan konseling di sekolah merupakan bagian yang tidak terpisahkan dari proses pendidikan, senantiasa terkait dengan perubahan yang terjadi pada kehidupan siswa dan masyarakat. Perubahan tersebut mencakup: (1) becoming, yaitu proses untuk menjadi dirinya, (2) being, yaitu proses untuk menemukan kebermaknaan hidup. Konselor melalui layanan bimbingan dan konseling berupaya menyediakan fasilitas agar siswa dapat membimbing, mengatur dan mengarahkan dirinya untuk mencapai perkembangan optimal dan memperoleh kebermaknaan hidup. Hal ini dapat diwujudkan melalui layanan bimbingan dan konseling yang memandirikan siswa.

Dengan demikian, layanan bimbingan dan konseling di sekolah pada dasarnya bertujuan untuk memfasilitasi siswa mengefektifkan kegiatan belajar, memberi arah bagi tercapainya kesuksesan sepanjang hayat, baik pada rentang tujuan jangka pendek, menengah maupun jangka panjang.

Layanan bimbingan dan konseling dapat memberi kontribusi terhadap penangan masalah belajar yang sering dialami oleh siswa, khususnya keadaan dimana prestasi yang diperoleh siswa tersebut dibawah tingkat kecerdasan atau IQ yang dimilikinya yang biasanya disebut underachiever. 


\section{METODE PENELITIAN}

Penelitian ini adalah penelitian kualitatif, yaitu penelitian yang bermaksud untuk memahami keadaan tentang apa yang dialami oleh subjek penelitian misalnya perilaku, persepsi, motivasi, tindakan, secara holistik, dan dengan cara deskripsi dalam bentuk katakata dan bahasa, pada suatu konteks khusus yang alamiah dan dengan memanfaatkan berbagai metode ilmiah (Moleong, 2010: 6)

Subjek penelitian adalah keseluruhan dari sumber informasi dan menunjukan pada orang atau individu atau kelompok yang dijadikan unit atau satuan khusus yang diteliti. Subjek penelitian yang dimaksud adalah informan atau sumber data, yaitu orang yang merespon atau menjawab pertanyaan peneliti. Adapun yang menjadi subjek penelitian adalah siswa, guru, dan orang tua di SDN Nambak Desa Nambak Kecamatan Bungkal Kabupaten Ponorogo. Sedangkan objek penelitian adalah data apa saja yang akan dicari (digali) dalam penelitian. (Arikunto, 2010: 344).

Untuk memperoleh data yang diharapkan, peneliti menggunakan teknik beberapa pengumpulan data. Adapun teknik pengumpulan data yang digunakan dalam penelitian ini adalah sebagai berikut:

1. Metode observasi adalah suatu pengamatan dan penulisan dengan sistematis terhadap gejala-gejala atau objek yang diteliti. (Hadi S, 2001:141). Metode ini dipakai untuk memperoleh data yang belum terdapat dalam interview dan dokumentasi. Teknik observasi yang dipergunakan dalam penelitian ini adalah observasi partisipan, yaitu peneliti ikut ambil bagian dalam kegiatan yang dilakukan orang yang diobservasi.

2. Wawancara adalah percakapan dengan maksud tertentu. Percakapan itu dilakukan oleh dua pihak, yaitu pewawancara (interviewer) yang mengajukan pertanyaan dan terwawancara (interview) yang memberikan jawaban atas pertanyaan itu. Dalam penelitian ini peneliti membuat format wawancara yang terkait dengan pelayanan bimbingan dan konseling terkait dengan underachiever siswa.

Dalam rangka menganalisis data-data yang diperoleh dari hasil penelitian maka disini diterapkan metode analisis data kualitatif. Dalam analisis data tersebut digunakan teknik analisis deskriptif kualitatif yaitu analisis data yang memberikan predikat pada variabel yang diteliti dengan kondisi yang sebenarnya. (Arikunto, 2010: 353).

Sedangkan analisis data dari penelitian ini, dilakukan berdasar analisis deskritif. Analisis tersebut terdiri dari tiga alur yang berinteraksi 
yaitu reduksi data, penyajian data dan penarikan kesimpulan (Sarwono, 2006:106).

\section{HASIL PENELITIAN}

Peran layanan bimbingan dan konseling untuk mengatasi siswa underachiever di SDN Nambak adalah membantu mengoptimalkan prestasi belajar siswa agar sesuai dengan kemampuan kecerdasan atau IQ yang dimilikinya, melalui berbagai program layanan sebagai berikut: Pertama, layanan dasar. Layanan ini bertujuan untuk membantu semua konseli agar memperoleh perkembangan yang normal, memiliki mental yang sehat, dan memperoleh ketrampilan hidup, atau dengan kata lain membantu konseli agar mereka dapat mencapai tugas-tugas perkembangan secara optimal. Strategi layanan dasar ini terdiri dari layanan orientasi, layanan informasi, bimbingan kelas dan bimbingan kelompok. Kedua, layanan responsif. Layanan ini merupakan pemberian bantuan kepada siswa underachiever dengan segera, agar siswa dapat mengatasi hambatan-hanbatan dalam proses pencapaian prestasi belajarnya. Kegiatan layanan responsif terdiri dari: konseling individual, konseling kelompok, konsultasi, kolaborasi dan home visit (kunjungan rumah).

Melihat pengertian, tugas dan wilayah konselor dalam seting pendidikan formal, dalam hal ini membantu anak-anak yang underachiever adalah dengan: Pertama, Menciptakan lingkungan belajar. Dalam membuat lingkungan belajar maka ada beberapa hal yang harus dipertimbangkan yaitu: bagaimana membantu anak untuk sukses, membantu anak untuk bisa bekerjasama secara nyaman. Disini seorang konselor harus berusaha bekerja sama dengan guru dan murid untuk sama-sama menciptakan lingkungan belajar yang nyaman. Konselor bisa masuk ke kelas untuk husus berdiskusi dengan murid untuk membahas bagaimana membuat kelas yang nyaman bagi semua. Misal penekanan pada menghargai persamaan dan perbedaan, memahami kelebihan dan kekurangan sesama teman. Konselor pun bisa mengangkat potensi anak yang underachiever untuk mengikatkan rasa kepercayaan dirinya.

Kedua, Respon terhadap kebutuhan anak. Konselor harus bekerja sama dengan guru untuk menyeimbangakan kegiatan, maksudnya adalah seimbang antara kegiatan yang terstruktur dan yang tidak terstruktur (penuh dengan kreativitas), mempertimbangkan gaya belajar anak. Di SDN Nambak Desa Nambak Kecamatan Bungkal Kabupaten Ponorogo terkadang masalah belajar muncul karena gurunya, cara menjelaskan pelajaran, metode yang digunakan tidak sesuai dengan karakteristik 
siswa. Hal-hal semacam itu yang membuat siswa kurang dapat menerima pelajaran yang disampaikan oleh guru, ada juga anak yang menghindari mata pelajaran tertentu, sehingga anak tersebut keluar pada saat jam pelajaran. Untuk menghindari halhal semacam itu, maka guru bimbingan dan konseling bekerja sama dengan guru mata pelajaran agar memantau setiap perkembangan siswa didalam kelas sampai siswa tersebut benar-benar berubah, karena tidak mungkin guru bimbingan dan konseling memantau keadaan siswa didalam kelas, sehingga diperlukan kerjasama dengan guru tanpa meninggalkan kordinasi antara keduanya. Untuk guru mata pelajaran tertentu yang sering dihindari oleh siswa, guru bimbingan dan konseling memberikan masukan untuk mengubah metode yang digunakan sesuai dengan karakteristik siswa.

Ketiga, Bekerjasama dengan orang tua. Peranan orang tua sangatlah penting dalam pelaksanaan bimbingan dan konseling untuk mengatasi siswa underachiever, pelaksanaan bimbingan dan konseling tidak akan maksimal jika tidak ada kerjasama dengan orang tua, karena dengan orang tua ikut proaktif dalam menyelesaikan permasalahan siswa, maka guru bimbingan dan konseling tidak akan kesulitan.
Memahamkan kepada setiap orangtua bahwa masing-masing anak unik, jadi tidak bisa dipaksakan bahwa setiap anak harus bisa dalam segala hal. Sehingga orang tua bisa menerima dan tidak hanya berfokus pada masalah yang muncul tapi juga pada potensinya. Dengan pemberian konseling kepada orangtua diharapkan untuk mampu membantu orangtua mengerti, memahami dan menerima anak sebagai seorang individu yang utuh yang memiliki kebutuhan sebagai individu; membantu orangtua dalam mengatasi gangguan emosi pada anak yang ada hubungannya dengan situasi keluarga di rumah; membantu orangtua mengambil keputusan dalam memilih sekolah bagi anaknya sesuai dengan taraf kemampuan kecerdasan, fisik dan inderanya; memberikan informasi kepada orangtua untuk memecahkan masalah-masalah pendidikan yang mungkin dialami oleh anaknya.

Hasil yang diperoleh setelah melaksanakan program bimbingan dan konseling untuk siswa underachiever adalah terdapat perubahan pada: Pertama, perubahan pada siswa. Siswa lebih aktif mengikuti pelajaran, disiplin terhadap tata tertip, perolehan nilai belajarnya meningkat, serta lebih bertenggung jawab dalam menyelesaikan tugas-tugas. Kedua, perubahan pada orang tua. Orang tua siswa menjadi lebih perhatian kepada anak dan lebih terlibat pada usaha 
anak dalam meningkatkan belajar serta hasil prestasi belajarnya. Ketiga, perubahan pada guru. Perubahan penilaian guru terhadap siswa berubah menjadi positif dan berharap siswa akan dapat mencapai target pembelajaran yang telah ditetapkan.

\section{KESIMPULAN DAN SARAN}

\begin{abstract}
Kebanyakan anak-anak underachiever, bukan dikarenakan dia tidak mampu atau IQ-nya dibawah rata-rata, akan tetapi karena adanya faktor lain yang mempengaruhi, faktor ini menyebabkan prestasi atau nilainya tidak sesuai dengan harapan, diantaranya adalah pengalaman belajar anak yang tidak menyenangkan ketika berada dikelas, gaya belajar siswa yang berbeda dengan gaya mengajar guru dan guru tidak mentolerir perbedaan itu, tekanan dari orangtua yang mungkin bagi anak menjadi suatu yang membuat mereka frustasi sehingga mengakibatkan prestasi buruk, dan masih banyak lagi hal yang dapat menyebabkan anak menjadi seorang underachiever.
\end{abstract}

Beberapa hal yang dapat dilakukan oleh konselor dalam memperbaiki kondisi seorang anak dengan underachiever adalah: menciptakan lingkungan belajar yang sesuai dengan kebutuhan anak, memberi respon positif terhadap semua kebutuhan anak,
Menyeimbangkan antara kegiatan bersama dan kegiatan yang bersifat individual, bekerjasama dengan orangtua, dan terbuka kepada setiap anak mengenai kondisi dan keadaan mereka.

Untuk peneliti selanjutnya adalah dapat mengkaji mengenai pemberian layanan lain yang dapat menumbukan kemampuan anak sesuai dengan taraf intelegensinya sehingga anak tidak mengalami underachiever.

\section{DAFTAR PUSTAKA}

Arikunto, S. (2010). Prosedur penelitian : Suatu Pendekatan Praktik (Edisi Revisi). Jakarta : Rineka Cipta.

Depdiknas. (2007). Penataan Pendidikan Profesional

Konselor dan Layanan

Bimbingan dan Konseling dalam Jalur Pendidikan

Formal. Bandung: Jurusan Psikologi Pendidikan FIP UPI Bandung Bekerjasama dengan PB.ABKIN.

Farah Grace Tita. (2015). Pengaruh Konseling Kelompok Terhadap Motivasi Berprestasi Siswa Underachiever. Skripsi Jurusan Psikologi Universitas Islam Negeri Sunan Ampel Surabaya. Hadi S. (2001). Metodologi Researd Jilid 2. Yogyakarta: Andi Ofset. 
Jonathan Sarwono. (2006). Metode Penelitian Kuantitatif dan Kualitatif. Yogyakarta. Graha ilmu.

Moleong, L. J. (2010). Metodologi Penelitian Kualitatif. Bandung: Remaja Rosda karya.

Prayitno dan Erman Amti. (2009).

Dasar-dasar Bimbingan dan Konseling. PT. Rineka Cipta. Jakarta.
Rafika Rahmawati. (2013). Bimbingan dan Konseling untuk Anak Underachiever. Pendidikan Luar Biasa Fakultas Ilmu Pendidikan Universitas Negeri

Yogyakarta.http://digilib.uinsby. ac.id/3305/4/Bab\%201.pdf

Utami Munandar, (2004). Pengembangan Kreatifitas Anak Berbakat. Jakarta: Rineka Cipta. 